\title{
6
}

\section{A NEW APPROACH TO AUSTRALIA}

In 1951 Sir George Harvie-Watt became managing director of The Consolidated Gold Fields of South Africa and in 1954 was appointed deputy chairman, assuming the role of chief executive officer in that year. In 1960 he became both chairman and chief executive officer. He remained as chairman until 1968. According to AP Cartwright, who wrote one of three histories of Consolidated Gold Fields, Harvie-Watt's appointment to the board was in keeping with the approach to appoint at least one director 'from the world of affairs outside the circle of specialists in mining and mining-finance. ${ }^{1}$ In fact, at his death in 1989, Harvie-Watt was described as belonging to that 'dwindling band of men whose careers straddled the law, the army, politics and business'. ${ }^{2}$ In Harvie-Watt, the London board gained a man of great experience and energy: a trained barrister, member of parliament, commissioned Territorial Army officer and commander of the 31st Battalion of the Royal Engineers (later commander of the 6th Anti-Aircraft Brigade). He served as aide-de-camp to King George VI and as Sir Winston Churchill's parliamentary private secretary during World War II, from 1941 to 1945 . Churchill, in offering him this wartime role reportedly said: 'What I am offering you is not a job 
down in the engine room. I am asking you to serve on the bridge. ${ }^{3}$ In the role he managed Churchill's relationships with members of the House of Commons, acting as his 'eyes and ears in the Commons', engaging with foreign delegations and providing Churchill with 'candid assessments', including on the views of colleagues and proceedings within parliament. ${ }^{4}$

Harvie-Watt was steeled in the experiences of politics and the competing challenges of a coalition government during the exigencies of wartime Britain. He recalled his decision to join Consolidated Gold Fields as a full-time director in 1951 as the 'greatest business and personal decision' he ever made. ${ }^{5} \mathrm{He}$ initially served as a director while still a member of the House of Commons. Harvie-Watt's experience of mining was limited; his only involvement was as a director of the gold mining company Globe \& Phoenix Gold Mining Company and its Phoenix Prince mine in Rhodesia. Instead, Harvie-Watt studied the history of Consolidated Gold Fields and came to his own conclusions about the direction it should be taking. According to Cartwright, Harvie-Watt 'had a capacity for hard work ... a wide knowledge of affairs and the ability to make up his mind quickly'. Further:

He studied the affairs of the company as thoroughly as he had been accustomed to study his brief ... The time came when the company's business occupied most of his working day and many of his evenings ... Harvie-Watt, surveying the affairs of Gold Fields, made up his mind that the company was relying too much on its old traditions and that it, too, would have to change its methods and adapt itself to the post-war world. He thought ... that it needed a more broadly-based investment programme in countries with stable governments. ${ }^{6}$

3 Harvie-Watt, Most of My Life, p. 3. An obituary of Harvie-Watt stated: 'Churchill would give Harvie-Watt one of his legendary cigars on occasion—and in return PPS [parliamentary private secretary] would have to take the brunt of his tirades and frustration, either at the course of the war or his treatment in the House of Commons' (The Times, 26 December 1989).

4 Roberts, Churchill: Walking with Destiny, pp. 668 and 741.

5 Harvie-Watt, Most of My Life, p. 208.

6 Cartwright, Gold Paved the Way, p. 245. 


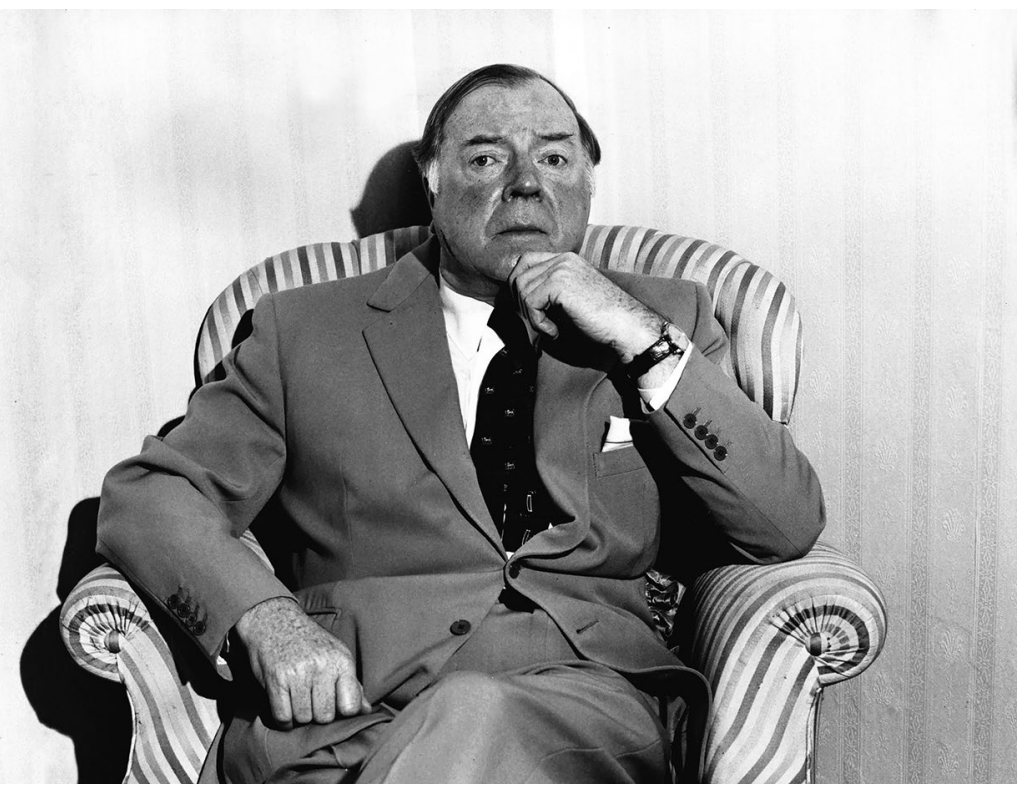

Figure 25. Sir George Steven Harvie-Watt, chairman and chief executive officer, Consolidated Gold Fields, responsible for overseeing a major investment program in Australia from 1960 and for the formation of Consolidated Gold Fields (Australia) Pty Ltd.

Source: George Lipman, Sydney Morning Herald, Nine Publishing.

Harvie-Watt realised that the company was at a crossroad. He decided that its investments in some of the 'unsafe parts of Africa' should be reduced; he viewed the company as too reliant on gold and too dependent upon a few mines in South Africa for its production. He changed the name of the company from The Consolidated Gold Fields of South Africa to Consolidated Gold Fields, to reduce the perceived reliance upon one geography. His view of the Gold Fields portfolio structure was that he 'wanted a carousel where all the horses were not down at the same time', reflecting a desire that the company did not have 'all of its interests in one commodity'. ${ }^{7}$ In this regard, investments in a range of industries, some outside mining, were viewed as appropriate. Harvie-Watt had a familiarity with Australia through his parliamentary responsibilities. He had visited Australia in 1950 en route to a Commonwealth parliamentary conference in New Zealand. During that visit, he travelled to the Lake View and

7 Harvie-Watt, Most of My Life, p. 240. 
Star mine in Western Australia. He recalled in later life that this visit 'stirred my imagination as to what Gold Fields might do in this land of opportunity'.

Several changes in company structure and funding arrangements provided the basis for an ambitious program of expansion in the 1960s, of which Australia was a key focus and an area of great success. In 1959 a restructuring occurred with the existing dual London company structure of Gold Fields of South Africa and New Consolidated Gold Fields abolished and the subsidiary company absorbed. South African interests were managed by Gold Fields of South Africa, with its head office in Johannesburg. A London-registered company, Gold Fields Mining \& Industrial, assumed responsibilities for all other international activities, including in Australia. In September 1960, Gold Fields Mining \& Industrial issued GBE5 million worth of debenture stock to fund its international expansion and in November of that year Consolidated Gold Fields (Australia) Pty Limited (CGFA) was formed to provide the basis for the group's expansion in Australia.

Despite the dearth of opportunities that had been generated in Australia to that time, the company's representative in Australia, Frank Beggs, expressed his concern that the new approach under Harvie-Watt entailed less of an emphasis on exploration and more on the acquisition of interests in other businesses. Beggs had visited London in October 1960 and wrote that he had 'heard about the new policy which is being doped out' and again expressed his concern that it would be 'wrong to give up on exploration'. ' However, Beggs could offer little promise that exploration efforts would turn up anything of significance, with his comment to his American colleague that 'we are still pushing on with Mt Isa with the Mining Corporation area but up to date it doesn't look at all hopeful'. ${ }^{10}$

By this stage, Gold Fields in London was orchestrating a wider program of investments in Australia. On 7 November 1960, the appointment of directors to CGFA occurred. Harvie-Watt, Beggs, Gilbert Potier, Keith Cameron and Tom Owen became the initial directors. Board meetings

8 ibid.

9 Letter from Frank R Beggs to Robt F Playter, 4 January 1960, Renison Goldfields Consolidated Archives (RGCA), 1430, Box 12300.

10 ibid. 
were held at 15 O'Connell Street in Sydney before office accommodation was leased and meetings held at the AMP building on Circular Quay from May 1962. By November 1960 Gold Fields in Australia had undertaken its first investment: Commonwealth Mining Investments (Australia).

Beggs, writing to his American colleague while surveying the scene, and with little apparent realisation of the magnitude of the changes about to unfold, recorded:

Other than this Commonwealth Mining business we have had very little excitement out here. We are still examining a large number of prospects and still being disappointed, but we have to keep on in the hope that somewhere, someday, we will turn up a worthwhile ore-body. ${ }^{11}$

Yet Gold Fields representatives from London were active in the country. Investments in Australia were assessed from Gold Fields' head office at 49 Moorgate, London. Gerald Mortimer, a senior Gold Fields manager and mining engineer, examined mineral sands opportunities in New South Wales, which also involved visiting steel works in the United Kingdom to evaluate the advantages of zircon in foundry applications, as well as surveying European demand for mineral sands. ${ }^{12}$ In 1963 Potier visited and met with the Western Australian Government in relation to the company's involvement in Mount Goldsworthy, while other representatives were in Australia, considering a range of investments, including oil exploration and production. ${ }^{13}$

The process of expansion in Australia was multifaceted and proceeded apace. By the mid-1960s, Consolidated Gold Fields had established a broad business foundation in Australia. The initial investment of the new Australian offshoot of Consolidated Gold Fields was a listed mining investment company, Commonwealth Mining Investments. Investments were made in copper, through the company's shareholding in The Mount Lyell Mining and Railway Company, Australia's oldest operating copper mine. Through this investment, subsequent control was achieved of Renison and the rich Tasmanian tin resources that proved valuable to CGFA and influenced its strategic considerations into the 1980s. A major

11 Letter from Frank R Beggs to Robt F Playter, 9 November 1960, RGCA, 1430, Box 12300.

12 'Note for File, Visit to North British Steel Foundry Limited, Bathgate, Scotland', 4 February 1963, RGCA, Box 12300.

13 Letter from Peter Wallis to SL Segal, 15 May 1962, RGCA, Box 12300. 
presence was established in iron ore through a founding involvement in, and development of, the Mount Goldsworthy iron ore deposits in the Pilbara of Western Australia in association with Cyprus Mining Corporation and Utah Construction \& Mining. In doing so, a BritishAmerican venture would be responsible for the first shipment of iron ore from the Pilbara in 1966.

CGFA, through separate investments in two east coast mineral sands producers, to be later supplemented by the acquisition and control of a west coast mineral sands producer, Western Titanium, established a dominant position in a mineral new to the group. While, under the aegis of New Consolidated Gold Fields (Australasia), exploration had been conducted with Utah on the Blackwater coal deposits in Queensland, an involvement in coal was gained by the acquisition of a majority interest in The Bellambi Coal Company, located near Port Kembla in New South Wales. Manufacturing interests were also established, with an investment in a New Zealand manufacturing company, Zip Holdings. The 1962 takeover of an Australian manufacturing company, RH Lawrenson, by a Consolidated Gold Fields-owned United Kingdom company, Alumasc Holdings, broadened the Australian entity's involvement in manufacturing when the renamed Lawrenson Alumasc Holdings, with manufacturing facilities at Lidcombe in New South Wales, became a subsidiary of CGFA.

The newly established CGFA relied initially on Harvie-Watt, his deputy chairman Potier, fellow director JD (Donald) McCall, as well as Mortimer for its expansion plans. Potier, an accountant by training, had served in the No. 210 Squadron in the Royal Air Force during World War II and been awarded a Distinguished Flying Cross with a bar. He flew Catalina flying boats and Liberators and amassed over 1,050 hours of operational flying time. 'A medium built man ... [with a] brisk, precise approach ... [he] built up an enviable reputation as a clever and astute businessman. ${ }^{\prime 14}$ He had lived in Australia and was supportive of and actively involved in the company's expansion. Analytical and investment resources were provided from London, with a young University of Cambridge-educated graduate, Edward (Ted) Wiles, relocating to Australia to assist Mortimer and others with the group's expansion before being made a permanent employee of CGFA.

14 The Times, 23 January 1968. Potier was appointed chairman and chief executive of Consolidated Gold Fields to succeed Sir George Harvie-Watt in January 1968. He died at the age of 53 on 11 January 1969. 


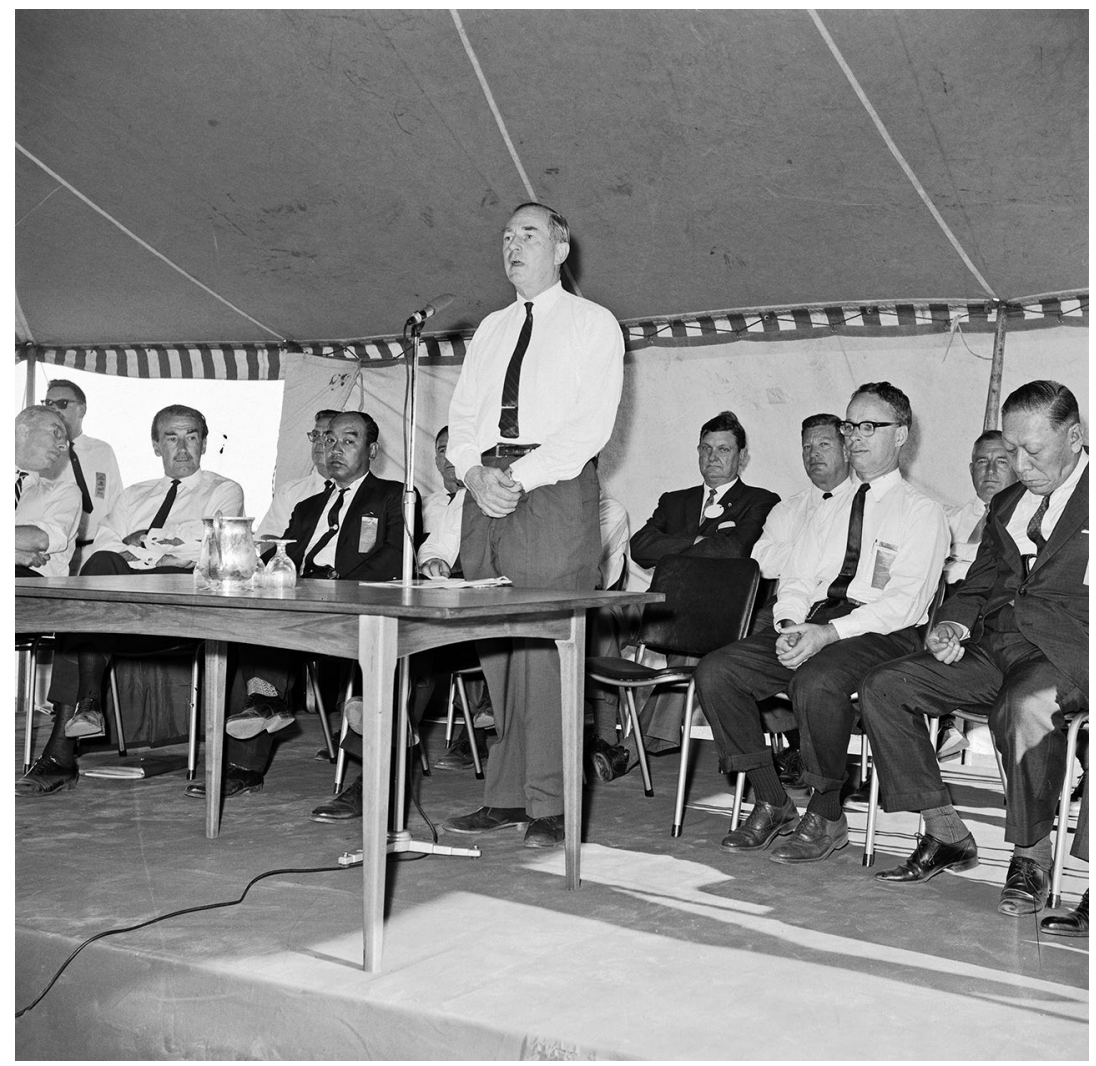

Figure 26. Brian Massy-Greene, appointed general manager of Consolidated Gold Fields (Australia) and managing director in 1962, speaking at the opening of the Mount Goldsworthy iron ore project in 1966.

Source: State Library of Western Australia (SLWA), Aerial Surveys Australia, BA 1475, 268349PD.

Local managerial resources were also strengthened. A 'man of calibre' was considered necessary to run the new Australian operation and John Brian Massy-Greene, son of Sir Walter Massy-Greene, a former federal minister and senator for New South Wales, was appointed general manager effective 14 May 1962. As a businessman, Massy-Greene was general manager at Austral Bronze, a subsidiary company of Metal Manufactures, which had been established by the Collins House Group and listed in 1916 for the production of copper wire. His father had been a director from 1933 to 1952 as well as known to Consolidated Gold Fields through its earlier investments in Australia. Daniel McVey, to be appointed a director of CGFA, was Metal Manufactures' long-serving managing director from 
1949 to $1962 .{ }^{15}$ Shareholders in Metal Manufactures included Mount Lyell Mining and Railway Company, a company in which CGFA would acquire a majority interest in $1964 .{ }^{16}$ The appointment of Massy-Greene was to begin a process of selecting men for senior managerial and directorial positions, well versed in business and with a standing in the community, although often with little direct mining experience.

In a letter to Beggs dated 25 June 1962, following the offer of his appointment by Potier, Massy-Greene wrote:

I understand that it is the intention of The Consolidated Gold Fields of South Africa Limited to maintain an enduring policy of investment in Australia and that there are no foreseeable circumstances which would cause the substantial withdrawal or disposal of their principal interests in this country.

Mr Potier advised me that it is the policy of the London Board that the main interests of Gold Fields situated outside England should be managed by citizens of the respective countries concerned. In this regard, he said that, irrespective of such substantial growth as may occur in Australia, it would not be the policy at a later date to make an appointment from London to take charge of the Company's interests here.

In the ordinary course of events I could anticipate that in due course I would succeed to the senior executive appointment in the Australian company. ${ }^{17}$

Massy-Greene did rise in the company and made a substantial contribution to its growth in Australia. He was appointed managing director in October 1962. Beggs left the company, departing with an offer to purchase the company's Daimler car. ${ }^{18}$ A newspaper article described Massy-Greene as an 'old school tie' man. When interviewed about his role at CGFA, he said there were three company ties: 'one for the South African companies, one for the British companies and one for directors' ${ }^{19}$ He became chairman in September 1966 when Harvie-Watt retired, to allow an Australian to

15 See Appendix 3 for a biographical profile of Brian Massy-Greene.

16 Ellis, Metal Manufactures Limited, pp. 26 and 36.

17 Consolidated Gold Fields (Australia) Pty Limited, 'Minutes of Meeting of Directors', 8 October 1962, RGCA, Box 12264.

18 Beggs was paid $A £ 20,000$ on retirement and offered to purchase the company's Daimler for A£3,000 (Consolidated Gold Fields (Australia) Pty Limited, 'Minutes of Meeting of Directors', 26 October 1962, RGCA, Box 12264).

19 The Australian, 10 April 1965. 
head the new publicly listed company as both chairman and managing director. Massy-Greene retained the dual roles until he was requested to step down as managing director at the behest of the London board in 1976. Sidney Segal, a South African-born lawyer and stockbroker, and formerly joint managing director of a company acquired by Consolidated Gold Fields of South Africa, New Union Goldfields, relocated to Australia in 1960 and was a highly influential senior finance executive and later director and long-serving chairman. ${ }^{20}$ Over the years that followed, board representation was strengthened to include notable Australian businessmen, including Sir Ian Potter and John Darling.

The portents for the future of the company in Australia were favourable. Speaking in 1987, Rudolph Agnew, the grandson of John Agnew, the man who was influential in the establishment of Consolidated Gold Fields' gold investments in Australia, referred to the 'brilliantly carried out' growth by acquisition in Australia that by the mid-1960s had established CGFA 'as a major force in the Australian mining industry'. ${ }^{21}$ The nature of that acquisition strategy and its inherent fragility will now be reviewed.

20 See Appendix 3 for a biographical profile of Sidney Segal.

21 Johnson, Gold Fields: A Centenary Portrait, p. 159. 
This text is taken from Consolidated Gold Fields in Australia: The Rise and Decline of a British Mining House, 1926-1998, by Robert Porter, published 2020 by ANU Press, The Australian National University,

Canberra, Australia.

doi.org/10.22459/CGFA.2020.06 